\title{
Effect of Concentration of Pectinase on Clarification and Ascorbic Acid of Lemon Ginger Drink
}

\author{
${ }^{*}$ Chrismita Budi Lusihanne \& Maria Marina Herawati \\ Agroteknologi/FPB - Universitas Kristen Satya Wacana, Salatiga - Indonesia 50711 \\ Received 03 June 2020, Revised 02 July 2020, Accepted 03 August 2020 \\ doi: 10.22487/j24775185.2020.v9.i3.pp133-138
}

\begin{abstract}
Lemon ginger drink is a herbal drink which contains many antioxidant and ascorbic acid that good for health. However, the murky appearance of the lemon ginger drink causes a lack of consumer interest especially young people in consuming this beverage. The murky in the lemon ginger drink is due to pectin content. Therefore, clarification is needed with the aid of a pectinase enzyme. The concentration of pectinase used in this study were 0; 0.04; 0.06; 0.08; 0.1; 0.1; and 0.12\%; then incubated at $500^{\circ} \mathrm{C}$ temperatures for 4 hours. The results showed the proper concentration of pectinase in the clarification of lemon ginger drink was $0.08 \%$. The concentration of the pectinase does not affect the ascorbic acid level of the lemon ginger drink.
\end{abstract}

Keywords: Lemon ginger drink, pectinase, clarification, ascorbic acid

\section{Pendahuluan}

Minuman jahe lemon adalah inovasi minuman fungsional berbahan baku jahe dengan tambahan perasa lemon untuk menambahkan sensasi yang menyegarkan. Minuman tersebut dikatakan sebagai minuman fungsional karena jahe mengandung oleoresin yang terdiri dari komponen shogaol dan gingerol serta lemon yang mengandung vitamin $\mathrm{C}$ memiliki peran sebagai antioksidan (Hidayat \& Rodame, 2015; Yi li, 2007). Selain itu, dengan mengonsumsi jahe dapat menurunkan kolesterol dan kadar glukosa darah, mencegah mabuk perjalanan, serta mengobati diare (Al-amin dkk., 2006; Olayaki dkk., 2007).

Berdasarkan penelitian pendahuluan yang telah dilakukan, yaitu uji organoleptik, sebanyak $80 \%$ panelis menyukai minuman jahe lemon ini. Akan tetapi, penampakan yang keruh dan pucat pada minuman jahe lemon menyebabkan kurangnya minat konsumen terutama anak muda saat akan mengonsumsi minuman tersebut. Menurut Beveridge (2002), adanya kekeruhan dan endapan pada minuman dianggap sebagai cacat produk, oleh karena itu mendapatkan presepsi yang negatif oleh konsumen. Proses klarifikasi dapat digunakan sebagai suatu metode dalam menjernihkan minuman jahe lemon. Kekeruhan pada minuman jahe lemon disebabkan karena adanya kandungan pektin. Pektin adalah senyawa polisakarida yang dapat mengentalkan cairan, mengikat air, atau membentuk gel. Senyawa pektin juga berguna sebagai perekat sel-sel serta jaringan (Iriani dkk., 2005). Apabila perekat tersebut berkurang maka minuman yang dihasilkan akan semakin jernih dan encer. Masalah ini biasanya juga terdapat pada beberapa kasus produksi jus buah atau sari buah.

Pada industri jus, keberadaan pektin dapat menjadi masalah untuk menghasilkan produksi jus yang jernih. Setiap produsen jus akan melakukan depektinasi. Jika tidak dilakukan depektinasi, pektin dapat mengendap pada produk akhir, kemudian minuman akan menjadi keruh dan berkabut atau bahkan berikatan dengan partikel lain membentuk partikel yang lebih besar Noer (2008).

Oleh karena itu, pada kasus ini, kekeruhan pada minuman jahe lemon harus diatasi dengan klarifikasi atau penjernihan. Klarifikasi minuman dapat dilakukan dengan bantuan enzim pektinase. Enzim pektinase bertujuan untuk mengurai pektin menjadi lebih sederhana agar mendapatkan minuman jahe lemon yang encer dan jernih (Hidayanti, 2016). Selain itu, proses klarifikasi yang baik dapat meningkatkan total padatan terlarut jahe lemon, dan mengurangi viskositas jahe lemon (Lee dkk., 2005; Handique, 2019).

Tulisan ini dimaksudkan untuk mengetahui konsentrasi enzim pektinase yang tepat dalam menghasilkan minuman jahe lemon yang jernih. Selain itu, perlu juga diketahui

${ }^{*}$ Correspondence:

Maria Marina Herawati

e-mail: maria.marina@uksw.edu

(c) 2020 the Author(s) retain the copyright of this article. This article is published under the terms of the Creative Commons Attribution License 4.0, which permits unrestricted non-commercial use, distribution, and reproduction in any medium, provided the original work is properly cited. 
pengaruh konsentrasi enzim pektinase terhadap kadar vitamin $\mathrm{C}$ pada minuman jahe lemon.

\section{Metode}

Alat-alat yang digunakan dalam penelitian ini yaitu inkubator (Memmert), spektrofotometer uv-vis 1280 (Shimadzu), viskometer ostwald (Blau Brand), vortex (Thermolyne), buret dan statif (no brand), hand refractometer (ATAGO N1), termometer batang (no brand), coloni counter (RKI 20-94).

Bahan-bahan yang digunakan dalam penelitian adalah jahe emprit lokal, lemon import, sukrosa (Gulaku), air, enzim pektinase (Java Brewcraft), aquades, reagen nelson, arsenomolybdat, amilum $1 \%$, iodin, media BPW (Buffered Peptone Water), media NA (Nutrient Agar) (Merck).

\section{Pembuatan Minuman Jahe Lemon}

Lemon sebanyak 37-40 gram diperas untuk diambil airnya. Jahe emprit sebanyak 60-63 gram dicuci dengan air mengalir, lalu dipanggang hingga lunak atau layu, kemudian digeprek agar bentuknya pipih. Jahe tersebut dimasukkan ke dalam panci berisi air sebanyak 1 liter. Ditambahkan gula pasir sebanyak 125-150 gram lalu direbus hingga mendidih. Setelah itu, dicampurkan dengan air perasan lemon pada saat suhu telah rendah (suam-suam kuku).

\section{Pengaplikasian Enzim Pektinase}

Minuman jahe lemon yang telah dibuat, diberi enzim pektinase dengan konsentrasi yang berbeda-beda yaitu $0 \%, 0.04 \%, 0.06 \%, 0.08 \%$, $0.1 \%$, dan $0.12 \%$. Proses inkubasi dilakukan pada suhu $50^{\circ} \mathrm{C}$ selama 4 jam. Enzim pektinase dipasteurisasi pada suhu $90^{\circ} \mathrm{C}$ selama 5 menit menggunakan waterbath (Vaidya dkk., 2009; Sin dkk., 2005).

\section{Uji Kejernihan}

Minuman jahe lemon diukur kejernihannya melalui pengukuran absorbansi pada panjang gelombang $660 \mathrm{~nm}$ menggunakan spektrofotometer dan aquades sebagai kontrol. Absorbansi yang terendah menunjukkan minuman yang paling jernih (Sin dkk., 2005).

\section{Uji Viskositas}

Uji viskositas dilakukan menggunakan viskometer ostwald dengan cara memasukkan sampel ke dalam pipa a sampai ruang $r$ penuh terisi. Kemudian cairan dihisap melalui pipa $b$ sampai naik melewati garis $\mathrm{m}$. Cairan dibiarkan turun sampai garis n (Iriani dkk., 2005). Dicatat waktu yang dibutuhkan cairan untuk mengalir dari garis $\mathrm{m} \mathrm{ke} \mathrm{n}$, lalu dihitung dengan rumus:

$$
\eta=\eta_{o} \frac{t x \rho}{t_{0} \times \rho_{0}}
$$

dimana $\eta$ adalah viskositas cairan sampel, $\eta_{o}$ adalah viskositas cairan pembanding, $t$ adalah waktu aliran cairan sampel, $t_{0}$ adalah waktu aliran cairan pembanding, $\rho$ adalah massa jenis cairan sampel, dan $\rho_{0}$ adalah massa jenis cairan pembanding.

\section{Uji TPT}

Sebanyak 1 tetes sampel minuman jahe lemon diteteskan pada prisma refraktometer yang telah dikalibrasi dengan aquades steril. Kemudian arahkan refraktometer ke sumber cahaya. Nilai yang terbaca menunjukkan besarnya total padatan terlarut pada sampel dalam derajat satuan Brix (Meikapasa dkk., 2016).

\section{Uji Kadar Gula Reduksi}

Sampel minuman jahe lemon diambil sebanyak $10 \mathrm{~mL}$ dan dimasukkan ke dalam labu takar $100 \mathrm{~mL}$, lalu ditambahkan aquades sampai batas tera. Diambil $1 \mathrm{~mL}$ fitrat dan ditambahkan 9 $\mathrm{mL}$ aquades (10x pengenceran), kemudian di vortex. Diambil $1 \mathrm{~mL}$ filtrat dari pengenceran 10x, kemudian ditambahkan $1 \mathrm{~mL}$ reagen nelson lalu dipanaskan selama 20 menit. Ditambahkan larutan arsenomolybdat $1 \mathrm{~mL}$ dan ditambahkan akuades $7 \mathrm{~mL}$. Absorbansi pada pengenceran 10x diukur menggunakan spektrofotometer dengan panjang gelombang $540 \mathrm{~nm}$. Kandungan gula reduksi ditentukan menggunakan rumus regresi deret standar (mg/mL) (Sudarmadji, 1996).

\section{Uji Vitamin C}

Sampel minuman jahe lemon diambil sebanyak $10 \mathrm{~mL}$ dan dimasukkan ke dalam labu takar ukuran $100 \mathrm{~mL}$ sampai batas tera dengan akuades. Kemudian disaring dengan menggunakan kertas saring lalu fitrat diambil sebanyak $10 \mathrm{~mL}$ dan dimasukkan kedalam erlenmeyer. Tahap selanjutnya ditambahkan $2 \mathrm{~mL}$ amilum $1 \%$ (sebagai indikator) dan ditambahkan $20 \mathrm{~mL}$ aquades. Larutan tersebut dikocok sampai tercampur dengan merata. Kemudian dititrasi dengan $\mathrm{I}_{2}$ (iodin) sampai warna larutan berubah menjadi warna biru (Iriani dkk., 2005). Volume titrasi lalu dicatat dan dihitung dengan rumus:

Kadar vitamin $\mathrm{C}$ dalam $10 \mathrm{~mL}=$ volume titrasi $\mathrm{x} 0.88 \mathrm{mg}$

Dimana $1 \mathrm{~mL}$ iodin setara dengan $0.88 \mathrm{mg}$ asam askorbat.

\section{Analisis Tingkat Cemaran E.coli}

Tingkat cemaran E.coli pada minuman jahe lemon dianalisis menggunakan metode angka lempeng total (ALT). Sampel minuman jahe lemon dengan perlakuan konsentrasi enzim pektinase yang terbaik diambil $1 \mathrm{~mL}$. Kemudian dimasukan ke dalam $9 \mathrm{~mL}$ media BPW (buffered peptone water) pada tabung reaksi, lalu dihomogenkan. Selanjutnya diambil $1 \mathrm{~mL}$ dan dimasukkan ke dalam $9 \mathrm{~mL}$ media BPW lalu dihomogenkan (pengenceran $10^{-1}$ ). Langkah tersebut dilakukan hingga pengenceran $10^{-4}$. Masing-masing pengenceran diambil sebanyak 1 $\mathrm{mL}$, dan dimasukkan ke dalam cawan petri yang 
telah berisi $15 \mathrm{~mL}$ media NA (nutrient agar), kemudian dihomogenkan dan ditutup rapat dengan plastik wrap. Diinkubasi pada suhu $37^{\circ} \mathrm{C}$ selama 48 jam (Hartati, 2016). Koloni E.coli yang nampak dihitung dengan coloni counter, lalu dihitung dengan rumus:

$$
A L T=\text { jumLah koloni setiap cawan } \mathrm{x} \frac{1}{\text { faktor pengenceran }}
$$

\section{Hasil dan Pembahasan}

Proses penjernihan atau klarifikasi minuman jahe lemon dilakukan menggunakan enzim pektinase. Enzim pektinase yang digunakan merupakan enzim pektinase murni yang terbuat dari apel. Pengujian klarifikasi minuman jahe lemon ditentukan secara kuantitatif menggunakan 4 parameter. Parameter yang digunakan meliputi total padatan terlarut (TPT), gula reduksi, viskositas, dan clarity (kejernihan). Disisi lain, dilakukan pengujian vitamin $\mathrm{C}$ untuk mengetahui pengaruh aplikasi enzim pektinase terhadap kadar vitamin $\mathrm{C}$ minuman jahe lemon.

\section{Total Padatan Terlarut}

Total padatan terlarut (TPT) adalah total terlarutnya zat padat di dalam suatu cairan, dimana zat padat yang dimaksud dalam penelitian ini adalah pektin. Adanya pektin dalam minuman jahe lemon membuat penampakan minuman jahe lemon menjadi keruh, sehingga perlu dilakukan klarifikasi (penjernihan) menggunakan enzim pektinase. Menurut Sin dkk. (2005) dan Barros dkk. (2004), reaksi enzimatik pada pektinase mampu memecah polimer pektin dan menyebabkan pektin-protein menggumpal, sehingga menghasilkan minuman yang jernih. Oleh karena itu, dalam reaksi enzimatik pada pektinase diperoleh peningkatan TPT (Arsad dkk., 2015).

Apabila dilihat pada Tabel 1, terjadi peningkatan TPT yang signifikan antara minuman jahe lemon yang tidak diberi enzim pektinase (konsentrasi $0 \%$ ) dengan minuman jahe lemon yang diberi enzim pektinase (konsentrasi $0.04-$ $0.12 \%$ ). Hal ini menunjukkan bahwa keberadaan enzim pektinase mampu mengatalis pektin menjadi senyawa larut (asam D-galakturonat) melalui reaksi depolimerisasi (Pedrolli dkk, 2009). Pektinase memiliki mekanisme lock and key, dimana sisi aktif dari pektinase hanya dapat bereaksi dengan ikatan glikosidik dari pektin (Christy dan Kavitha, 2014).

Table 1. Hasil pengujian klarifikasi minuman jahe lemon

\begin{tabular}{cccccc}
\hline $\begin{array}{c}\text { Konsentrasi } \\
\text { enzim } \\
\text { pektinase } \\
(\%)\end{array}$ & $\begin{array}{c}\text { TPT } \\
(\% \text { Brix })\end{array}$ & $\begin{array}{c}\text { Gula } \\
\text { Reduksi } \\
(\mathrm{mg} / \mathrm{mL})\end{array}$ & $\begin{array}{c}\text { Viskositas } \\
(\mathrm{cP})\end{array}$ & $\begin{array}{c}\text { Clarity } \\
(\mathrm{abs})\end{array}$ & $\begin{array}{c}\text { Vitamin C } \\
(\mathrm{mg} / 10 \mathrm{~mL})\end{array}$ \\
\hline 0.00 & $9.95 \mathrm{C}$ & $1.604 \mathrm{C}$ & $1.709 \mathrm{~A}$ & $0.364 \mathrm{~A}$ & $2.64 \mathrm{~A}$ \\
0.04 & $10.80 \mathrm{~B}$ & $2.010 \mathrm{~B}$ & $1.572 \mathrm{~B}$ & $0.103 \mathrm{~B}$ & $2.42 \mathrm{~A}$ \\
0.06 & $11.25 \mathrm{AB}$ & $2.127 \mathrm{AB}$ & $1.522 \mathrm{~B}$ & $0.084 \mathrm{~B}$ & $2.42 \mathrm{~A}$ \\
0.08 & $11.50 \mathrm{~A}$ & $2.364 \mathrm{~A}$ & $1.565 \mathrm{~B}$ & $0.056 \mathrm{~B}$ & $2.42 \mathrm{~A}$ \\
0.10 & $11.15 \mathrm{AB}$ & $2.138 \mathrm{AB}$ & $1.574 \mathrm{~B}$ & $0.067 \mathrm{~B}$ & $2.42 \mathrm{~A}$ \\
0.12 & $10.90 \mathrm{~B}$ & $2.003 \mathrm{~B}$ & $1.550 \mathrm{~B}$ & $0.083 \mathrm{~B}$ & $2.42 \mathrm{~A}$ \\
\hline
\end{tabular}

Pada konsentrasi enzim $0.04 \%$ hingga $0.08 \%$ terjadi peningkatan TPT, akan tetapi terjadi penurunan TPT pada konsentrasi enzim $0.1 \%$ hingga $0.12 \%$. Hal ini menunjukkan bahwa reaksi enzimatik dalam melarutkan pektin terjadi sangat cepat hingga tingkat konsentrasi enzim tertentu, yaitu $0.08 \%$. Penurunan reaksi enzimatik terjadi pada konsentrasi enzim $0.1 \%$ hingga $0.12 \%$ sehingga menyebabkan total pektin yang terlarut tidak sebanyak pada konsentrasi $0.08 \%$. Hal ini terjadi dikarenakan adanya pengaruh antara konsentrasi enzim dengan suhu dan waktu inkubasi yang mempengaruhi optimasi hidrolisis pektin (Sharma dkk., 2014).

Optimasi hidrolisis pektin pada minuman jahe lemon terjadi pada konsentrasi enzim $0.08 \%$, walaupun jika dilihat dari parameter TPT tidak berbeda secara signifikan dengan konsentrasi enzim $0.06 \%$ dan $0.1 \%$. Pada penelitian klarifikasi jus oleh Lee dkk. (2005) menyatakan bahwa, reaksi enzimatik akan terjadi sangat cepat seiring dengan penambahan konsentrasi enzim hingga taraf tertentu, kemudian reaksi akan berjalan lambat setelah melampaui konsentrasi optimum. Hal ini diduga karena semua substrat yang tersedia sudah terikat dengan enzim pektinase (mekanisme lock and key), sehingga saat dilakukan penambahan enzim tidak ada lagi pektin yang terlarut dalam minuman (Beals dkk., 1999).

\section{Gula Reduksi}

Kadar gula reduksi merupakan jumLah polisakarida dalam suatu sampel yang tereduksi menjadi monosakarida. Gula reduksi berbanding lurus dengan TPT. Oleh sebab itu, apabila TPT meningkat maka kadar gula reduksi juga akan meningkat dalam penjernihan minuman, karena adanya reaksi enzimatik dari pektinase (Arsad dkk., 2015).

Berdasarkan hasil penelitian yang disajikan pada Tabel 1, parameter gula reduksi memiliki koding yang sama dengan parameter 
TPT. Hal ini menunjukkan bahwa terjadi peningkatan kadar gula reduksi yang signifikan antara minuman jahe lemon yang tidak diberi enzim pektinase (konsentrasi 0\%) dengan minuman jahe lemon yang diberi enzim pektinase (konsentrasi $0.04-0.12 \%$ ). Pada konsentrasi enzim $\quad 0.04 \%$ hingga $0.08 \%$ juga terjadi peningkatan kadar gula reduksi, kemudian terjadi penurunan kadar gula reduksi pada konsentrasi enzim $0.1 \%$ hingga $0.12 \%$. Optimasi dari gula yang tereduksi bergantung pada optimasi hidrolisis pektin pada reaksi enzimatik, yang juga berbanding lurus dengan optimasi pektin yang terlarut. Oleh sebab itu, titik optimum kadar gula reduksi berada pada perlakuan konsentrasi enzim $0.08 \%$, sehingga mengindikasikan minuman jahe lemon yang paling jernih, walaupun tidak berbeda nyata dengan konsentrasi enzim $0.06 \%$ dan $0.1 \%$.

\section{Viskositas}

Viskositas adalah ukuran yang menyatakan kekentalan dari suatu cairan. Adanya pektin dalam minuman jahe lemon menyebabkan penampakan minuman menjadi keruh dan memiliki viskositas yang tinggi (Iriani dkk., 2005; Sin dkk., 2005). Oleh sebab itu, apabila pektin menjadi larut dan tereduksi, maka viskositas dari minuman akan mengalami penurunan.

Pada Tabel 1, perlakuan tanpa enzim (konsentrasi enzim 0\%) menunjukkan tingkat viskositas yang lebih tinggi dibandingankan dengan perlakuan penambahan enzim (konsentrasi 0.04\%-0.12\%). Hal ini menunjukkan perbedaan yang signifikan, sebab adanya reaksi enzimatik dari pektinase mampu mendegradasi pektin yang akan mengurangi daya ikat air, kemudian akan melepaskan free water ke sistem sehingga dapat mengurangi viskositas dari minuman jahe lemon (Lee dkk., 2005). Viskositas dari minuman jahe lemon juga dipengaruhi oleh data total padatan terlarut dan gula reduksi yang tersaji pada Tabel 1. Peningkatan gula reduksi dan total padatan yang larut, menyebabkan penurunan viskositas dari minuman jahe lemon. Reaksi enzimatik dalam klarifikasi minuman jahe lemon memberikan hasil yang sensitif terhadap total pektin yang terlarut dan pektin yang tereduksi, namun kurang sensitif terhadap parameter viskositas. Hal ini ditunjukkan dengan perbedaan yang tidak nyata antara perlakuan konsentrasi enzim $0.04 \%$ hingga $0.12 \%$.

\section{Kejernihan}

Kejernihan (clarity) suatu cairan atau sampel diukur sederhana menggunakan spektrofotometer dengan panjang gelombang 660 $\mathrm{nm}$. Oleh karena itu, parameter clarity menggunakan data dengan satuan absorbansi. Absorbansi merupakan banyaknya cahaya yang diserap dalam suatu sampel. Semakin rendah absorbansi suatu sampel maka mengindikasikan bahwa semakin jernih minuman tersebut, sebab semakin banyak cahaya yang mampu melewati (transmitran) sampel tersebut.

Berdasarkan hasil penelitian yang disajikan pada Tabel 1, perlakuan tanpa enzim (konsentrasi enzim 0\%) memiliki nilai absorbansi yang paling tinggi dibandingkan dengan perlakuan penambahan enzim (konsentrasi enzim $0.04 \%-0.12 \%$ ). Hal ini menunjukkan perbedaan yang signifikan, sehingga minuman jahe lemon dengan perlakuan penambahan enzim memiliki penampakan yang lebih jernih (Gambar 1). Kejernihan suatu minuman ditentukan oleh TPT, gula reduksi, dan kekentalan (viskositas) dari minuman tersebut (Iriani dkk., 2005). Adanya penambahan enzim pektinase dalam minuman jahe lemon menyebabkan peningkatan total pektin yang larut dan tereduksi, serta menurunkan viskositas, sehingga diperoleh minuman jahe lemon yang jernih.

Parameter clarity tidak memiliki perbedaan yang signifikan antara perlakuan enzim $0.04 \%$ hingga $0.12 \%$. Hal ini membuktikan bahwa reaksi enzimatik dalam klarifikasi minuman jahe lemon memberikan hasil yang kurang sensitif terhadap parameter clarity.

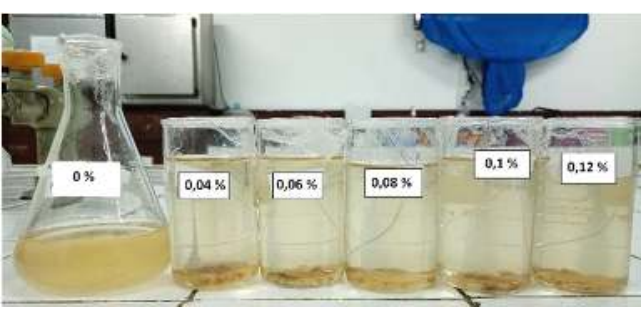

Gambar 1. Penampakan minuman jahe lemon setelah diaplikasikan enzim pektinase

\section{Vitamin C}

Kadar vitamin C pada minuman jahe lemon diukur menggunakan metode titrasi iodimetri sehingga diperoleh data asam askorbat. Menurut penelitian Joshi dkk., (2011), adanya hidrolisis pektin oleh enzim pektinase tidak mempengaruhi kadar asam askorbat pada jus. Berdasarkan hasil penelitian pada minuman jahe lemon (Tabel 1), terjadi penurunan kadar vitamin $\mathrm{C}$ (asam askorbat) pada minuman jahe lemon yang diberi enzim pektinase, akan tetapi tidak menunjukkan perbedaan yang nyata dengan perlakuan tanpa 
enzim. Hal ini disebabkan karena vitamin $\mathrm{C}$ yang terdapat dalam minuman jahe lemon dilindungi oleh gula selama proses pengolahan, sehingga vitamin $\mathrm{C}$ yang hilang selama proses pengolahan hanya sedikit (Mukaromah dkk., 2010). Menurut Winarno (2004), asam askorbat berada dalam keseimbangan dengan asam dehidroaskorbat, kemudian pada suasana asam, cincin lakton asam dehidroaskorbat terurai menjadi senyawa diketogulonat sehingga vitamin $\mathrm{C}$ terlindung dengan adanya gula.

\section{Tingkat Cemaran E.coli}

Suatu produk minuman layak dikonsumsi oleh masyarakat apabila aman dan bersih dari komponen atau mikroba yang berbahaya. Menurut Alwi \& Maulina (2012), keberadaan mikroba dalam suatu minuman merupakan salah satu parameter biologis untuk menentukan kelayakan suatu produk minuman untuk dikonsumsi. Salah satu cara untuk mengukur keberadaaan cemaran mikroba tersebut adalah menggunakan metode angka lempeng total (ALT). ALT merupakan metode kuantitatif untuk menguji cemaran mikroba dalam suatu sampel pangan dengan perhitungan jumLah koloni mikroba aerob yang diperoleh (Rizal, 2016).

Setelah diperoleh konsentrasi enzim pektinase yang terbaik dalam klarifikasi minuman jahe lemon, maka dilakukan uji cemaran mikroba menggunakan metode ALT. Cemaran mikroba yang menjadi fokus uji adalah bakteri Escherichia coli. Menurut Chandra (2006), keberadaan E.coli dalam suatu makanan atau minuman merupakan indikasi pasti terjadinya kontaminasi. E.coli dipilih sebagai indikator karena mikroba ini mudah ditemukan dimana-mana termasuk di dalam air yang telah terkontaminasi debu dan binatang kecil. Hasil pengujian tingkat cemaran E.coli pada sampel minuman jahe lemon disajikan dalam Tabel 2.

Tabel 2. ALT pada minuman jahe lemon

\begin{tabular}{ccccc}
\hline Batas max ALT & ALT sampel & ALT sampel & ALT sampel & ALT sampel \\
$(\mathrm{SNI} 7388: 2009)$ & $10^{-1}$ & $10^{-2}$ & $10^{-3}$ & $10^{-4}$ \\
\hline $2.10^{2} \mathrm{koloni} / \mathrm{mL}$ & $0 \mathrm{koloni} / \mathrm{mL}$ & $0 \mathrm{koloni} / \mathrm{mL}$ & $0 \mathrm{koloni} / \mathrm{mL}$ & $0 \mathrm{koloni} / \mathrm{mL}$ \\
\hline
\end{tabular}

Hasil pengujian ALT bakteri E.coli menunjukkan bahwa, pada minuman jahe lemon tidak terdapat cemaran mikroba apapun termasuk cemaran E.coli sehingga aman dari batas SNI. Hal itu ditunjukkan dengan tidak adanya koloni yang tumbuh khususnya koloni bakteri E.coli seperti pada Gambar 2. Oleh sebab itu, minuman jahe lemon layak untuk dikonsumsi oleh masyarakat.

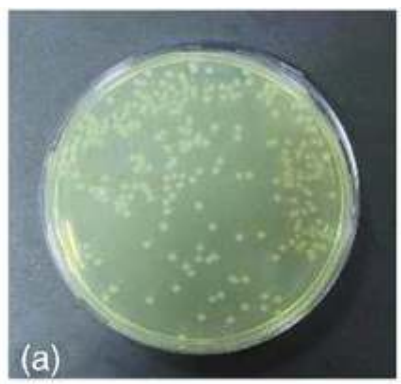

Gambar 2. Cemaran E.coli pada media NA

(Savas dan Hancer, 2015)

\section{Kesimpulan}

Konsentrasi enzim pektinase yang tepat dalam klarifikasi minuman jahe lemon adalah $0.08 \%$. Konsentrasi enzim pektinase tidak mempengaruhi kadar vitamin $\mathrm{C}$ minuman jahe lemon.

\section{Ucapan Terima Kasih}

Ucapan terima kasih penulis ucapkan kepada Universitas Kristen Satya Wacana yang telah membantu dan mendukung selama proses penelitian melalui hibah internal penelitian terapan.

\section{Referensi}

Al-Amin, Z. M., Martha T., Khaled, K. A., Riitta P. S., \& Muslim, A. (2006). Antidiabetic and hypolipidaemic properties of ginger (zingiber officinale) in streptozotocin-induced diabetic rats. The British Journal of Nutrition, 96(4), 660-666.

Alwi, M., \& Maulina. (2012). Pengujian bakteri coliform dan escherichia coli pada beberapa depot air minum isi ulang di Kecamatan Palu Timur Kota Palu. Jurnal Biocelebes, 6(1), 4047.

Arsad, P., Sukor, R., Wan, I. W. Z., Mustapha, N. A., \& Meor, A. S. (2015). Effect of enzymatic 
treatment on physicochemical properties of sugar palm fruit juice. International Journal on Advance Science Engineering and Information Technology, 5(5), 308-312.

Barrosi, S. T. D., Mendes, E. S., \& Peres, L. (2004). Influence of depectinization in the ultrafiltration of west indian cherry (malpighia glabra 1.) and pineapple (ananas comosus (1.) meer) juices. Food Science and Technology, 24(2), 194-201.

Beals, M., Gross., L., \& Harrell, S. (1999). Enzymes and the rate of chemical reactions. Diakses tanggal 23 Juni 2020 dari http://www.tiem.utk.edu/ gross/bioed/webm odules/enzymes.htm.

Beveridge, T. (2002). Opalescent and cloudy fruit juices: Formation and particle stability. Critical Reviews in Food Science and Nutrition, 42(4), 317-337.

Chandra, B. (2006). Pengantar kesehatan lingkungan. Jakarta: EGC.

Christy, P. B., \& Kavitha, S. (2014). Role of enzymes. International Journal of Recent Scientific Research, 5(6), 1181-1183.

Handique, J., Sandhan, J. B., \& Nandan, S. (2019). Optimization of banana juice extraction using combination of enzymes. Journal Food of Science and Technology, $56(6), 1-12$.

Hartati, F. K. (2016). Evaluasi pengujian angka lempeng total menggunakan metode petrifilm aerobic count plate terhadap metode uji sni 01.2332.2006 pada produk perikanan di LPPMHP surabaya. Jurnal Teknik Industri Heuristic, 13(2), 89-105.

Hidayanti, N. (2016). Aplikasi enzim poligalakturonase dan pektinesterase pada klarifikasi sari buah naga super merah (hylocereus costaricensis). Skripsi Tidak Diterbitkan. Surakarta: Universitas Sebelas Maret.

Hidayat, S., \& Rodame M. N. (2015). Kitab tumbuhan obat. Jakarta: Agriflo.

Iriani, E. S. E., Gumbira, S., Ani, S., \& Setyadjit. (2005). Pengaruh konsentrasi penambahan pektinase dan kondisi inkubasi terhadap rendemen dan mutu jus mangga kuini (mangifera odorata griff). Jurnal Pascapanen, 2(1), 11-17.

Joshi, V., Mukesh, P., \& Neerja, R. (2011). Purification and characterization of pectinase produced from apple pomace and evaluation of its efficacy in fruit juice extraction and clarification. Indian Journal of Natural Products and Resources, 2(2), 189-197.

Lee, W. C., Yusof, S., Hamid, N., \& Baharin, B. S. (2006). Optimizing conditions for enzymatic clarification of banana juice using response surface methodology (RSM). Journal of Food Engineering, 73(1), 55-63.
Meikapasa, N. W. P., \& Seventilofa, I. G. N. O. (2016). Karakteristik total padatan terlarut (TPT) stabilitas likopen, dan vitamin C pada saus tomat pada berbagai suhu dan kombinasi waktu pemasakan. Ganec Swara, 10(1), 8186.

Mukaromah, U., Sri, H. S., \& Siti, A. (2010). Kadar vitamin $\mathrm{C}$, mutu fisik, $\mathrm{pH}$ dan mutu organoleptik sirup rosella (hibiscus sabdariffa, 1) berdasarkan cara ekstraksi. Jurnal Pangan dan Gizi, 1(1), 43-51.

Noer, H. (2008). Pectinase: Small, but important. Diakses tanggal 23 Juni 2020 dari http://foodreview.biz.

Olayaki, L. A., Ajibade, K. S., Gesua, S. S., \& Soladoye, A. O. (2007). Effect of zingiber officinale on some hematologic values in alloxan-induced diabetic rats. Pharmaceutical Biology, 45(7), 556 - 559.

Pedrolli, D. B., Alexandre, C. M., Eleni, G., \& Eleonora, C. C. (2009). Pectin and pectinases: production, characterization and industrial application of microbial pectinolytic enzymes. The Open Biotechnology Journal, 3(1), 9-18.

Rizal, M. (2016). Analisis kandungan mpn dan alt pada fish nugget berbahan dasar limbah ikan. Jurnal Biologi Sel, 5(2), 144-151.

Savas, L. A., \& Hancer, M. (2015). Montmorillonite reinforced polymer nanocomposite antibacterial film. Applied Clay Science, 108, 40-44.

Sharma, H. P., Hiral, P., \& Sugandha, S. (2014). Enzymatic extraction and clarification of juice from various fruits. Trends in Post Harvest Technology, 2(1), 1-14.

Standar Nasional Indonesia (SNI) 7388. (2009). Batas maksimum cemaran mikroba dalam pangan. Badan Standarisasi Nasional.

Sin, H. N., Yusof, S., Hamid, A. S. N., \& Rahman, A. R. (2005). Optimization of enzymatic clarification of sapodilla juice using response surface methodology. Journal of Food Engineering, 73(4), 313-319.

Sudarmadji. (1996). Prosedur analisa untuk bahan makanan dan pertanian. Yogyakarta: Liberty.

Vaidya, D., Manoj, V., Surabhi, S., \& Ghanshayam. (2009). Enzymatic treatment for juice extraction and preparation and preliminary evaluation of kiwifruits wine. Natural Product Radiance, 8(4), 380-385.

Winarno, F. G. (2004). Kimia pangan dan gizi. Jakarta: PT Gramedia.

Yi Li, \& Schellhorn, H. E. (2007). New development and novel therapeutic perspective for vitamin C. Journal Nutrition, 137(10), 2171-84 